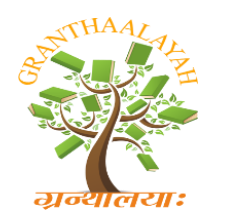

\author{
INTERNATIONAL JOURNAL OF RESEARCH - \\ GRANTHAALAYAH \\ A knowledge Repository
}

Management

\title{
AWARENESS AND ATTITUDES OF CONSUMERS TOWARDS FOOD SAFETY IN THOOTHUKUDI DISTRICT
}

\author{
R. Anantha Laxmi ${ }^{* 1}$ \\ ${ }^{* 1}$ PhD Research Scholar, PG and Research Department of Commerce, V. O. Chidambaram \\ College, Thoothukudi, INDIA
}

DOI: https://doi.org/10.29121/granthaalayah.v4.i7(SE).2016.2627

\begin{abstract}
The issue of consumer preferences for food safety has proved to be somewhat of a conundrum. Research on this subject has yielded conflicting results and the empirical data are scarce. There are a number of studies that has identified the need for continued efforts towards educating consumers on the hazards of improper food handling. Common mistakes identified in food handling include serving contaminated raw food, cooking or heating food inadequately, having infected persons handle implicated food and practice poor hygiene. This paper gives a comprehensive picture of the awareness and attitudes of consumers towards food safety in Thoothukudi district. A sample size of one hundred and ten respondents is selected for the research from Thoothukudi district. The study quantitatively analyses the awareness of food safety practices, attitudes and behaviors of the consumers in executing food safety knowledge and practices and food safety practices and its impact on food borne diseases using the primary data. Appropriate findings and suggestions are given in the paper.
\end{abstract}

Keywords:

Food safety, Food borne diseases, Food safety knowledge and practices.

Cite This Article: R. Anantha Laxmi, “AWARENESS AND ATTITUDES OF CONSUMERS TOWARDS FOOD SAFETY IN THOOTHUKUDI DISTRICT”, International Journal of Research - Granthaalayah, Vol. 4, No. 7: SE (2016): 44-54.

\section{INTRODUCTION}

Food safety experts and enforcement agencies today agree that microbiological spoilage and contamination of food with pathogens represent the most severe and costly health hazards in connection with food. Microbial pathogens in food cause an estimated 6.5-33 million cases of human illness and up to 9000 deaths in the one country each year. Over 40 different food borne microbial pathogens, including fungi, viruses, parasites, and bacteria, are believed to cause human illness. Food safety is designed as the degree of confidence that food will not cause sickness or harm to the consumer when is prepared, served and eaten. Food can be mishandled at 
any number of places during food preparation, handling and storage; and studies show that consumers have inadequate knowledge about measures needed to prevent food borne illness in home. Contaminated raw foods, inadequate cooking, and consumption of food from an unsafe source were the factors most commonly associated with reported outbreaks of food borne illnesses.

\section{STATEMENT OF THE PROBLEM}

The global incidence of food borne illness is difficult to estimate but it has been reported that in 2000 alone 2.1 million people died from diarrhea diseases. A great proportion of these cases can be attributed to contamination of food and drinking water. The Centre for Diseases Control and Prevention (CDCP) has estimated that food borne contaminants cause approximately 76 million illness, 3,25,000 hospitalizations and 5000 death each year. Food safety knowledge is associated with current practices. Actual food handling practices are known to differ from self-reported practices. The main factors responsible for the outbreaks of food poisoning were inappropriate storage, inadequate cooking or reheating, and cross-contamination. Particular attention should be given to the importance of time and temperature control, personal hygiene, cross contamination, sources of contamination and the factors determining the survival and growth of pathogenic organisms in food. Many people do not know the basic rules of food hygiene and they have been suffering from food borne diseases as per the World Health Organization. Hence the researcher has made an attempt to find out existing awareness and attitudes of consumers in food handling practices and its impact on food borne diseases.

\section{RESEARCH OBJECTIVES}

The following are the objectives of the study

- To examine the awareness of food safety practices of the consumers before preparing food at home.

- To analyze attitudes and behaviors of the consumers in executing food safety knowledge and practices.

- To examine the food safety practices and its impact on food borne disease.

\section{HYPOTHESES}

The following are the hypotheses to be tested in the study

Awareness of food safety practices in preparing food entirely does not depend on the education of the respondents.

Type of house of the respondents does not influence the prevalence of food borne illness.

\section{RESEARCH DESIGN AND METHODOLOGY}

Since the present study has its own predetermined objectives and methodology, it is analytical in nature. It has made an attempt to explain the consumer awareness and attitudes towards food safety and also the impact on food borne diseases caused by the lack of knowledge on safe food handling practices. 


\subsection{SCOPE OF THE STUDY}

The present study covers the Thoothukudi district of Tamil Nadu. It deals with awareness and attitudes of consumers living in Thoothukudi district towards food safety. The period of this study is about six months (i.e.,) from July 2015 to January 2016.

\subsection{SAMPLING DESIGN}

By adopting random sampling method, respondents were selected from various parts of Thoothukudi district. The sample size of this study is 110. A structured interview schedule was used to collect the relevant data.

\subsection{SOURCE OF DATA}

The present study is based on both primary data and secondary data. Primary data were collected through the interview schedules. Secondary data were collected through websites, articles, journals and books.

\subsection{COLLECTION OF DATA}

A well-structured schedule was used to collect primary data from the respondents. The interview schedule consists of four important parts. The first part covers the demographic profile of the respondents. The second part of the schedule includes the awareness of food safety practices among the respondents. The third part of the schedule includes the attitude and behaviour of the respondents and its impact on food borne diseases. A pilot study was conducted among 20 respondents based on the feedback of the pilot study, modifications, additions and deletions were carried out. The final draft was prepared to collect the data.

\subsection{FRAME WORK OF ANALYSIS}

The data were analysed by using the Statistical Package for Social Sciences (SPSS) software package version 20. The tools include Inferential Statistics, Chi-square Analysis, One way analysis of variance, Correlation and Multiple Regression.

\section{RESULTS AND DISCUSSION}

In the study, frequency infers the respondents' occurrence level on awareness of food safety. Chi-square Analysis has been used to analyze the relationship between the profile of the respondents and their health problems. One way Analysis of variance has been used to find out the relationship between the education of the respondents and their awareness on food safety. Multiple regression analysis has been used to find out the knowledge and awareness of food safety importance given to cleaning of vessels, certified foods and attractive packages. 


\subsection{CONSUMERS'AWARENESS ON FOOD SAFETY}

Food safety control measures are almost certainly as old as human history itself. Food can be mishandled at any number of places during food preparation, cooking and storage, and evidence indicates that consumers have inadequate knowledge about the measures needed to prevent foodborne illness in the home. Consumers are the important final link in the food chain to assure safe food consumption. Multiple food safety responsibilities are required during home food preparation and failure to assume personal responsibility for food safety at home may result in increased potential for unsafe food-handling behaviours and consequential increased risks of illness.

Table 1: Education and Awareness of Food Safety

\begin{tabular}{|c|c|c|c|c|c|c|}
\hline Awareness & Education & $N$ & Mean & Std. Deviation & F value & $P$ value \\
\hline \multirow{3}{*}{ Checking Labels } & Illiterate & 3 & 1.33 & .577 & \multirow{3}{*}{6.041} & \multirow{3}{*}{$.003 *$} \\
\hline & School Level & 40 & 3.88 & 1.202 & & \\
\hline & College Level & 67 & 3.67 & 1.248 & & \\
\hline \multirow{3}{*}{ Buying Fresh Foods } & Illiterate & 3 & 2.33 & .577 & \multirow{3}{*}{2.295} & \multirow{3}{*}{$.106^{*}$} \\
\hline & School Level & 40 & 3.28 & 1.037 & & \\
\hline & College Level & 66 & 3.53 & 1.084 & & \\
\hline \multirow{3}{*}{ Identification } & Illiterate & 3 & 2.33 & 1.155 & \multirow{3}{*}{.896} & \multirow{3}{*}{$.411 *$} \\
\hline & School Level & 40 & 3.05 & 1.300 & & \\
\hline & College Level & 67 & 3.24 & 1.268 & & \\
\hline \multirow{3}{*}{ Handling Pets } & Illiterate & 3 & 3.67 & .577 & \multirow{3}{*}{.063} & \multirow{3}{*}{$.939 *$} \\
\hline & School Level & 40 & 3.95 & 3.226 & & \\
\hline & College Level & 67 & 3.81 & 1.373 & & \\
\hline \multirow{3}{*}{ Sterlize Food } & Illiterate & 3 & 4.67 & .577 & \multirow{3}{*}{.156} & \multirow{3}{*}{$.856^{*}$} \\
\hline & School Level & 40 & 4.38 & .838 & & \\
\hline & College Level & 67 & 4.37 & .935 & & \\
\hline \multirow{3}{*}{ Cleaning of Nails } & Illiterate & 3 & 3.67 & 1.528 & \multirow{3}{*}{.816} & \multirow{3}{*}{$.445^{*}$} \\
\hline & School Level & 40 & 4.15 & 1.027 & & \\
\hline & College Level & 67 & 4.30 & .905 & & \\
\hline
\end{tabular}

*Significant at $5 \%$ level

Table 1 shows the relationship between education of the consumers and their awareness on food safety. As per the acceptance of null hypothesis ( $>0.05)$, the variables of buying fresh foods, identification, handling pets, sterilize foods, cleaning of nails are not significantly associated with the awareness of food safety. It is clear from the analysis that the awareness of food safety does not influence the education of consumers.

In other variable of checking labels, as per the rejection of null hypothesis $(\mathrm{p}<0.05)$, there is a significant association between education and awareness of food safety. Awareness of food safety is significantly related with the education of respondents. Consumers with high level of literacy and education have more awareness on the checking of labels in the packaged foods. 
Table 2: Education and Checking of information

\begin{tabular}{|c|c|c|c|c|c|c|}
\hline $\begin{array}{l}\text { Checking } \\
\text { information }\end{array}$ & Education & $N$ & Mean & Std. Deviation & F value & P value \\
\hline \multirow{3}{*}{ Manufacturedate } & Illiterate & 3 & 1.33 & .577 & \multirow{3}{*}{8.433} & \multirow{3}{*}{$.000 *$} \\
\hline & School Level & 40 & 3.73 & 1.377 & & \\
\hline & College Level & 67 & 4.13 & 1.113 & & \\
\hline \multirow{3}{*}{ Expirydate } & Illiterate & 3 & 2.33 & 1.528 & \multirow{3}{*}{5.323} & \multirow{3}{*}{$.006^{*}$} \\
\hline & School Level & 40 & 3.53 & 1.240 & & \\
\hline & College Level & 67 & 4.04 & 1.036 & & \\
\hline \multirow{3}{*}{ Ingredients } & Illiterate & 3 & 2.33 & 1.528 & \multirow{3}{*}{.735} & \multirow{3}{*}{$.482 *$} \\
\hline & School Level & 40 & 3.05 & 1.395 & & \\
\hline & College Level & 67 & 3.21 & 1.274 & & \\
\hline
\end{tabular}

*Significant at $5 \%$ level

Table 2shows the relationship between education and checking of information on the packaged foods. As per the acceptance of null hypothesis $(p>0.05)$, the variables of expiry date and ingredients are not significantly associated with the checking of information. It is clear from the analysis that the checking of information does not influence the education of respondents.

In other variables of manufacture date, as per the rejection of null hypothesis $(\mathrm{p}<0.05)$, there is a significant association between education and checking of information. Checking of information relating to the manufacture date is significantly related with the education of respondents. The educated respondents always check the manufacturing date of the products brought by them from stores.

Table 3: Education and sources of awareness on food safety

\begin{tabular}{|c|c|c|c|c|c|c|}
\hline Awareness & Education & $N$ & Mean & $\begin{array}{l}\text { Std. } \\
\text { Deviation }\end{array}$ & F value & P value \\
\hline \multirow{3}{*}{ Attend seminar } & Illiterate & 3 & 1.00 & .000 & \multirow{3}{*}{1.264} & \multirow{3}{*}{$.287 *$} \\
\hline & School Level & 40 & 1.60 & .982 & & \\
\hline & College Level & 67 & 1.79 & .993 & & \\
\hline \multirow{3}{*}{ Magazines } & Illiterate & 3 & 1.67 & .577 & \multirow{3}{*}{4.445} & \multirow{3}{*}{$.014^{*}$} \\
\hline & School Level & 40 & 3.65 & 1.210 & & \\
\hline & College Level & 67 & 3.48 & 1.064 & & \\
\hline \multirow{3}{*}{ Watching TV } & Illiterate & 3 & 3.67 & .577 & \multirow{3}{*}{.246} & \multirow{3}{*}{$.783 *$} \\
\hline & School Level & 40 & 3.93 & 1.047 & & \\
\hline & College Level & 67 & 4.45 & 5.022 & & \\
\hline \multirow{3}{*}{ Internet } & Illiterate & 3 & 1.00 & .000 & \multirow{3}{*}{5.958} & \multirow{3}{*}{$.004 *$} \\
\hline & School Level & 40 & 2.05 & 1.377 & & \\
\hline & College Level & 67 & 2.90 & 1.519 & & \\
\hline \multirow{3}{*}{ Friends } & Illiterate & 3 & 4.00 & 1.000 & \multirow{3}{*}{2.514} & \multirow{3}{*}{$.086 *$} \\
\hline & School Level & 40 & 4.60 & .778 & & \\
\hline & College Level & 67 & 4.18 & 1.072 & & \\
\hline
\end{tabular}

*Significant at $5 \%$ level 
Table 3 shows the relationship between education and awareness towards food safety. As per the acceptance of null hypothesis ( $\mathrm{p}>0.05)$, the variables of attending seminar, magazines, watching TV and friends are not significantly associated with the awareness towards food safety. It is clear that the awareness towards food safety does not influence the education of respondents.

In other variables of internet, as per the rejection of null hypothesis $(p<0.05)$, there is a significant association between education and awareness towards food safety. Awareness towards food safety from internet is significantly related with the education of respondents. It is concluded that highly educated respondents choose internet as their medium of source of awareness.

\subsection{FOOD SAFETY KNOWLEDGE AND PRACTICES}

The food safety knowledge of the consumers is associated with their current practices, which in turn affects the willingness to change current practices, if it is learned that current practices are unsafe. However, actual food handling practices are known to differ from self-reported practices. World Health Organisation reported that particular attention should be given to the importance of time and temperature control, personal hygiene, cross contamination, sources of contamination and the factors determining the survival growth of pathogenic organisms in food. Food behaviours and breaches of good hygiene practice can predispose consumers to a number of health consequences. Information on actual consumer behaviour in relation to purchasing, transporting, storing, preparing and consuming food is essential to develop and underpin food safety promotional activities. From a consumer perspective the main food safety behaviours associated with foodborne illness are inadequate washing of hands, utensils, chopping boards and dishcloths, inadequate washing of fruit and vegetables, improper storing, chilling and cooking of meat and chicken, cross-contamination of ready-to-eat foods and consumption of raw contaminated foods.

Table 4: Occupation and food safety knowledge and practices

\begin{tabular}{|c|c|c|c|c|c|c|}
\hline Food Safety knowledge & Occupation & $N$ & Mean & $\begin{array}{l}\text { Std. } \\
\text { Deviation }\end{array}$ & F value & $P$ value \\
\hline \multirow{5}{*}{ Cook sufficient for one day } & Business & 10 & 4.50 & .707 & \multirow{5}{*}{.837} & \multirow{5}{*}{$.504 *$} \\
\hline & Government & 17 & 4.47 & .874 & & \\
\hline & Private & 45 & 4.09 & 1.164 & & \\
\hline & House Wife & 37 & 4.05 & 1.201 & & \\
\hline & Daily Wages & 1 & 5.00 & & & \\
\hline \multirow{5}{*}{ Reheat food whenever use } & Business & 10 & 4.00 & 1.054 & \multirow{5}{*}{.903} & \multirow{5}{*}{$.465^{*}$} \\
\hline & Government & 17 & 4.18 & .809 & & \\
\hline & Private & 45 & 3.80 & 1.160 & & \\
\hline & House Wife & 37 & 4.05 & .705 & & \\
\hline & Daily Wages & 1 & 5.00 & . & & \\
\hline \multirow{4}{*}{ Taste the food through fingers } & Business & 10 & 4.30 & 1.252 & \multirow{4}{*}{1.891} & \multirow{4}{*}{$.117 *$} \\
\hline & Government & 17 & 3.41 & 1.064 & & \\
\hline & Private & 45 & 3.44 & 1.159 & & \\
\hline & House Wife & 37 & 3.68 & 1.029 & & \\
\hline
\end{tabular}


*Significant at $5 \%$ level

Daily Wages $1 \quad 2.00$.

Table 4.5 shows the relationship between occupation and food safety knowledge of the consumers. As per the acceptance of null hypothesis ( $p>0.05)$, the variables of cook sufficient for one day, reheat food whenever use and taste the food through fingers are not significantly associated with the food safety knowledge. It is clear from the analysis that the food safety knowledge does not influence the occupation of the respondents. The occupation of the consumers does not determine their level of knowledge on the food safety measures.

Table 5: Education and Knowledge and practices related to food preparation

\begin{tabular}{|c|c|c|c|c|c|c|}
\hline $\begin{array}{l}\text { Knowledge and } \\
\text { practices related to food } \\
\text { preparation }\end{array}$ & Education & $\mathbf{N}$ & Mean & Std. Deviation & F value & $P$ value \\
\hline \multirow{3}{*}{ Cleaning Kitchen } & Illiterate & 3 & 4.00 & 1.000 & \multirow{3}{*}{.096} & \multirow{3}{*}{$.909 *$} \\
\hline & School Level & 40 & 4.25 & .981 & & \\
\hline & College Level & 67 & 4.25 & .990 & & \\
\hline \multirow{3}{*}{ Washing Hands } & Illiterate & 3 & 4.33 & .577 & \multirow{3}{*}{.150} & \multirow{3}{*}{$.861 *$} \\
\hline & School Level & 40 & 4.25 & .840 & & \\
\hline & College Level & 67 & 4.16 & .931 & & \\
\hline \multirow{3}{*}{ Cleaning Surface } & Illiterate & 3 & 3.00 & 1.000 & \multirow{3}{*}{.578} & \multirow{3}{*}{$.563 *$} \\
\hline & School Level & 40 & 3.68 & .829 & & \\
\hline & College Level & 67 & 3.64 & 1.164 & & \\
\hline \multirow{3}{*}{$\begin{array}{l}\text { Washing } \\
\text { Vegetables }\end{array}$} & Illiterate & 3 & 4.00 & 1.000 & \multirow{3}{*}{.455} & \multirow{3}{*}{$.635^{*}$} \\
\hline & School Level & 40 & 4.35 & .802 & & \\
\hline & College Level & 67 & 4.43 & .857 & & \\
\hline \multirow{3}{*}{$\begin{array}{l}\text { Washing } \\
\text { Soap }\end{array}$} & Illiterate & 3 & 4.00 & 1.000 & \multirow{3}{*}{.658} & \multirow{3}{*}{$.520 *$} \\
\hline & School Level & 40 & 4.30 & .823 & & \\
\hline & College Level & 67 & 4.45 & .892 & & \\
\hline
\end{tabular}

*Significant at $5 \%$ level

Table 5shows the relationship between education and knowledge and practices related to food preparation. As per the acceptance of null hypothesis ( $p>0.05)$, the variables of cleaning kitchen, washing hands, cleaning surface, washing fresh vegetables and washing hands with soap are not significantly associated with the food safety knowledge and practices related to food preparation.

It is clear from the analysis that the food safety knowledge and practices related to food preparation is not influenced by the education of respondents.

Table 6: Knowledge and Awareness of Food Safety-Regression

\begin{tabular}{llllll}
\hline \multirow{2}{*}{ Model } & \multicolumn{2}{l}{$\begin{array}{l}\text { Unstandardized } \\
\text { Coefficients }\end{array}$} & $\begin{array}{l}\text { Standardized } \\
\text { Coefficients } \\
\text { Beta }\end{array}$ & $\begin{array}{l}\boldsymbol{t} \\
\text { value }\end{array}$ & $\begin{array}{l}\text { Sig. } \\
\text { value }\end{array}$ \\
\hline (Constant) & 1.616 & .420 & & 3.847 & $.000^{*}$ \\
\hline
\end{tabular}




\begin{tabular}{llllll}
\hline $\begin{array}{l}\text { Cleaning kitchen } \\
\text { counter }\end{array}$ & .481 & .081 & .502 & 5.911 & .000 \\
\hline Cleaning Vessels & .149 & .090 & .140 & 1.653 & .101 \\
\hline
\end{tabular}

* Significant at $5 \%$ level

Dependent Variable : Cleaning Kitchen before cooking food

Independent Variable : Cleaning kitchen counter and cleaning vessels

$\mathrm{R}$ value $\quad: 0.567$

R square $\quad: 0.321$

Adjusted R square $\quad: 0.309$

F value $\quad: 25.349$

$P$ value of ANOVA $: 0.000$

From the above table $6, \mathrm{R}^{2}$ describes the amount of variability that has been caused by independent variables of cleaning kitchen counter and cleaning vessels. Here it is (0.321) $32 \%$. Adjusted $\mathrm{R}^{2}$ gives the indication whether there is a significant factor or not. It should be close to $\mathrm{R}$ value. Here $\mathrm{R}^{2}(0.321)$ and adjusted $\mathrm{R}^{2}(0.309)$ are close to each other which indicates a good model. (Adjusted $\mathrm{R}^{2}$ always $<$ or $=\mathrm{R}^{2}$ ).

In regression analysis, $\mathrm{R}^{2}$ values will always increase with the inclusion of parameters but adjusted $\mathrm{R}^{2}$ may not be. This indicates the present of nuisance parameters in the model. The significant $\mathrm{p}$ value for $\mathrm{F}$ test indicates that at least one variable has significant contribution to the model. $\mathrm{R}^{2}$ is a measure designed to indicate strength on the impact on cleaning kitchen counter and cleaning vessels. The number can between 0 and 1 with values closer to one, meaning a strong relationship and $32 \%$ of variation in cleaning kitchen which is connected by the independent variables of cleaning kitchen counter and cleaning vessels. This analysis indicates that there is a relationship between cleaning kitchen counter and the independent variables of cleaning kitchen counter and cleaning vessels. The variable Cleaning kitchen counter has more impact than the variable Cleaning vessels as its $p$ value is less than the 0.5 level of significance.

\subsection{IMPACT ON FOOD BORNE DISEASES}

Food can be mishandled at any number of places during food preparation, handling and storage; and studied show that consumers have inadequate knowledge about measures needed to prevent food borne illness in the home. Contaminated raw foods, inadequate cooking, and consumption of food from an unsafe source were the factors most commonly associated with reported outbreaks of food borne illness in homes. They usually result from the consumption of contaminated food, pathogenic bacteria, viruses, or parasites that contaminate food. Food borne illness usually arises from improper handling, preparation, and food storage. During food preparation, preference should be given to health aspect in order to avoid food borne diseases. Proper food safety practices play a vital role in prevention of food borne diseases.

Table 7: Age and Causes for food borne illness (Bacterial effect)

\begin{tabular}{lllllll}
\hline Causes & Age & $N$ & Mean & $\begin{array}{l}\text { Std. } \\
\text { Deviation }\end{array}$ & F value & P value \\
\hline Harmful Bacteria & 18-21 years & 11 & 3.27 & 1.009 & 1.159 & $.329^{*}$ \\
\hline
\end{tabular}




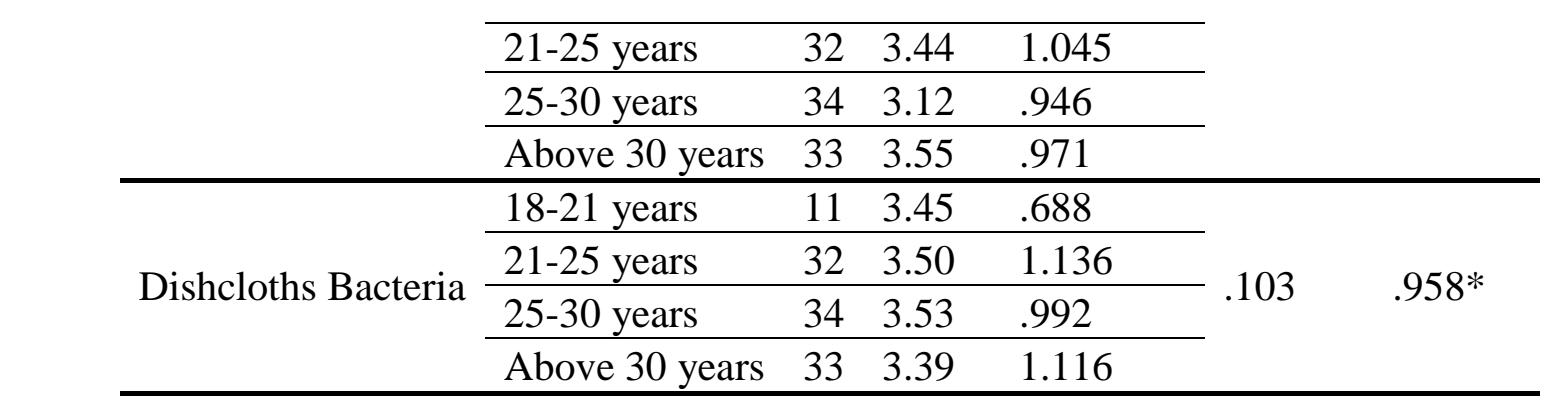

*Significant at $5 \%$ level

Table 7shows the relationship between age and causes for food borne illness. As per the acceptance of null hypothesis ( $p>0.05)$ the variables of harmful bacteria and dishcloths bacteria are not significantly associated with the causes for food borne illness. It is clear from the analysis that the cause for food borne illness due to bacterial effect is not influenced by the age of respondents.

Table 8: Type of house and Types of health problems

\begin{tabular}{|c|c|c|c|c|c|c|c|}
\hline \multirow{2}{*}{$\begin{array}{l}\text { Types } \\
\text { of } \\
\text { House }\end{array}$} & & \multicolumn{5}{|c|}{ Health problem } & \multirow[b]{2}{*}{ Total } \\
\hline & & Fever & $\begin{array}{l}\text { Head } \\
\text { ache }\end{array}$ & Vomiting & $\begin{array}{l}\text { Abdominal } \\
\text { pain }\end{array}$ & Diarrhea & \\
\hline \multirow{3}{*}{ Tiled } & Respondents & 3 & 11 & 10 & 1 & 11 & 36 \\
\hline & House types & $8.3 \%$ & $30.6 \%$ & $27.8 \%$ & $2.8 \%$ & $30.6 \%$ & $100.0 \%$ \\
\hline & $\begin{array}{l}\text { Health } \\
\text { problem }\end{array}$ & $37.5 \%$ & $52.4 \%$ & $25.0 \%$ & $7.1 \%$ & $40.7 \%$ & $32.7 \%$ \\
\hline \multirow{3}{*}{ Terrace } & Respondents & 5 & 10 & 30 & 13 & 16 & 74 \\
\hline & House types & $6.8 \%$ & $13.5 \%$ & $40.5 \%$ & $17.6 \%$ & $21.6 \%$ & $100.0 \%$ \\
\hline & $\begin{array}{l}\text { Health } \\
\text { problem }\end{array}$ & $62.5 \%$ & $47.6 \%$ & $75.0 \%$ & $92.9 \%$ & $59.3 \%$ & $67.3 \%$ \\
\hline \multirow{3}{*}{ Total } & Count & 8 & 21 & 40 & 14 & 27 & 110 \\
\hline & House types & $7.3 \%$ & $19.1 \%$ & $36.4 \%$ & $12.7 \%$ & $24.5 \%$ & $100.0 \%$ \\
\hline & $\begin{array}{l}\text { Health } \\
\text { problem }\end{array}$ & $100.0 \%$ & $100.0 \%$ & $100.0 \%$ & $100.0 \%$ & $100.0 \%$ & $100.0 \%$ \\
\hline
\end{tabular}

Source: Primary Data

Table 8shows the relationship between type of house and health problems of the consumers. Out of the 110 respondents, $67.3 \%$ of the respondents are living in terrace houses. Among them, majority of the respondents $(40.5 \%)$ are affected by vomiting and $21.6 \%$ of the respondents are affected by diarrhea. Further $32.7 \%$ of the respondents are living in tiled houses. Among them, $30.8 \%$ of the respondents are affected by head ache and diarrhea and $27.8 \%$ of the respondents affected by vomiting.

Table 9: Association of Type of house and Types of health problems

\begin{tabular}{llll}
\hline Factors & Value & df & $\begin{array}{l}\text { Sig. } \\
\text { value }\end{array}$ \\
\hline Pearson Chi-Square & 9.802 & 4 & $0.044^{*}$ \\
\hline
\end{tabular}




\begin{tabular}{llll}
\hline Likelihood Ratio & 10.751 & 4 & 0.030 \\
\hline $\begin{array}{l}\text { Linear-by-Linear } \\
\text { Association }\end{array}$ & 0.465 & 1 & 0.495 \\
\hline N of Valid Cases & 110 & & \\
\hline
\end{tabular}

*Significant at $5 \%$ level

Table 9shows the association between the type of house and health problems of the consumers. As per the acceptance of null hypothesis ( $>>0.05$ ), types of health problems is significantly associated with the type of house of the respondents. Type of house influences the types of health problems. The consumers living in hut, tiled and terrace houses have health problems irrespective of their house type.

\section{FINDINGS OF THE STUDY}

- Awareness of food safety is significantly related with the education of respondents. Consumers with high level of literacy and education have more awareness on the checking of labels in the packaged foods.

- Checking of information relating to the manufacture date is significantly related with the education of respondents. The educated respondents checked the manufacturing date of the products brought by them from stores.

- Highly educated respondents choose internet as their medium of source of awareness.

- The occupation of the consumers does not determine their level of knowledge on the food safety measures.

- Food safety knowledge and practices related to food preparation is not influenced by the education of respondents.

- There is a relationship between cleaning kitchen counter and the independent variables of cleaning kitchen counter and cleaning vessels. Cleaning kitchen counter has more impact than cleaning vessels as its $p$ value is less than the 0.5 level of significance.

- Food borne illness due to bacterial effect is not influenced by the age of respondents. Type of house influences the types of health problems. The consumers living in hut, tiled and terrace houses have health problems irrespective of their house type.

\section{SUGGESTIONS AND CONCLUSION}

Food safety knowledge tends to increase with age and practice: females have higher scores than males, and younger respondents have shown the greatest need for additional food safety education. The government should create awareness about practical execution of food safety. Hence, the government health officials should advise the respondents to prevent food borne diseases. Most of the respondents have less awareness about the food borne diseases. Awareness should be created about the risks of improper hand washing methods.

\section{REFERENCES}

[1] Senauer, B., Asp, E., and J. Kinsey. (1991). Food Trends and the Changing Consumer. St. Paul, MN: SAS Institute, Inc. 
[2] Bruhn, C.M., and Schutz, H. G. (1999). Consumer food safety knowledge and practices. Journal of food safety, 19, 73-87

[3] Baker, G. A., and P. J. Crosbie. 1994. "Consumer Preference for Food Safety Attributes: A Market Segment Approach.” Agribusiness: An International Journal, 10, 319-324.

[4] Regi, S. B. S, ARG (2014). “. A DESCRIPTIVE STUDY ON THE ROLE OF CONSUMER PSYCHOLOGY AND BEHAVIOUR IN PRODUCT PURCHASING”. Indian Streams Research Journal, 3.

[5] European Commission. (2000). February. Precautionary principle.

[6] Newsletters. WHO Surveillance programme for control of foodborne infections and intoxicants in Europe (2000).

[7] FO/WHO. (2003). Codex Alimentarius, Basic text on food Hygiene.

[8] Mederios, L., Hillers, v., Kendall, P., and Mason, A. (2001). Evaluation of food safety education for consumers.

[9] Albert,J.A. (1995). Food safety Knowledge and practices of consumers in the USA. Journal of consumer studies and Home Economics, 19,119-134.

[10] Golden, S. A. R., "MOBILE SUBSCRIBERS'ATTITUDE TOWARDS SERVICE TARIFF WITH SPECIAL REFERENCE TO TUTICORIN DIST”, International Journal of Research - Granthaalayah, Vol. 4, No. 3: SE (2016): 1-6. 